\title{
Gertrude Prokosch Kurath
}

\author{
August 19, 1903-August 1, 1992
}

by

Joann Kealiinohomoku

Gertrude's mother was a concert pianist; her father, the Sterling Professor of German at Yale University. She had two brothers, one an author, the other an airport architect. During her formative years, family friend Curt Sachs played piano for the Prokosch household. With her family, Gertrude traveled extensively, especially in Bavaria and Germany, where she studied Dalcroze Eurhythmics with Rudolf Bode.

At the University of Chicago (1919-1920) Gertrude studied dance with Margaret H'Doubler and anthropology with Frederick Starr. After earning her BA (1922) and MA (1928) from Bryn Mawr College in History of Art and Archaeology, she took and taught classes at the Yale School of Drama for a year. Over time she mastered several dance forms, studying with Placido de Monteliu, Riva Hoffman, Hans Wiener, Elsa Findlay, Ronny Johannsen, and Doris Humphrey.

In 1930 Gertrude married Hans Kurath (d. January, 1992). Their daughter, Ellen (b. 1934) and son Edward (b. 1937) both survive their parents.

In 1932 Gertrude founded the Rhode Island Creative Dance Guild, which she directed until 1946. During those years she taught, choreographed, and performed at many venues, including Ted Shawn's University of Dance. In 1946, when Hans joined the faculty at the University of Michigan, the family moved to Ann Arbor.

Since nepotism rules kept Gertrude from teaching at UM, she turned ner attention to field studies of dance. She took her first field trip in 1926 to study the Algonquian Indians, and from 1946 until the mid-sixties pursued field studies among many different Indian groups in Mexico and North America. She also pursued a long-time interest in popular and sacred dances of African Americans and analyzed the dances of immigrants and temporary residents in Michigan.

When, in 1947, Gertrude developed a working relationship with anthropologist William Fenton, she received a theoretical and practical initiation into the discipline of anthropology. At his invitation she went to the field with him to observe and analyze dances that Fenton believed vitally important to a holistic study of the Iroquois, but which eluded his analytical expertise. Although she had no degree in anthropology, her contributions to this field were recognized by Sol Tax (University of Chicago), who invited her to participate in professional seminars and panels. As editor of Current Anthropology, Tax asked Gertrude to write her seminal article, "Panorama of Dance Ethnology" (1960:233-54).

Gertrude did not identify herself as an anthropologist. She coined the term "ethnochoreologist", to parallel the term "ethnomusicologist", but it never became firmly fixed in the vocabulary. Her interest in the ethnomusicological approach reflected her emphasis on the interrelationship of music and dance-performance as an aural as well as a visual event. She called her work "the study of dance and music in relation to a way of life" (personal communication: Ellen Kurath,
1992). A charter member of the Society for Ethnomusicology, she was dance editor for Ethnomusicology from 1956 to 1971.

As a trained musician she was adept in writing music scores; as a dance scholar she valued dance scores as mnemonic aids and as analytical tools. She respected and knew the work of Rudolf Laban. When Gertrude co-authored Dances of Anahuac with Samuel Marti (Chicago: Aldine Press, 1964) they asked Nadia Chilkovsky (Nahumck) to contribute Labanotation.

Gertrude devised ways to conduct field work in dance, process the work for analysis, and make her work accessible through her writing. Although she was knowledgeable about Labanotation, she realized that most readers of her work were illiterate in notation systems. For that reason, as well as to develop a field "shorthand", as she called it, she invented glyph writing, drawing strongly on Laban's notation system.

Gertrude's first major article about a non-western dance culture, "Los Concheros," was published in the Journal of American Folklore (1946, 59:387-99). By the time a special bibliography of her works was printed in Ethnomusicology (Kealiinohomoku and Gillis 1970, XIV:114-28), she had 50 major publications to her credit, of which 9 were books. She had also published 116 reviews of books, records, and dance programs, and numerous brief articles and notes; had published in 26 journals; and produced a record with notes, Songs and Dances of Great Lakes Indians, for Ethnic Folkways (1956, FE4003).

She contributed entries to numerous encyclopedias and wrote 600 entries for the Dictionary of Folklore, Mythology and Legends (New York: Funk and Wagnalls, Maria Leach, ed., 1949-50). When Doris Humphrey died in 1958, Gertrude succeeded her as dance consultant to Webster's International Dictionary. To my knowledge Gertrude was the first dance scholar to credit her major informant as her co-author: with the publication of Music and Dance of the Tewa Pueblos she lists herself as author "with Antonio Garcia" (a man from San Juan Pueblo).

Throughout her life Gertrude continued to write, and she performed publicly until a 1974 hip injury permanently limited mobility. In spite of many years of field work and writing, she considered herself, first and foremost, a dancer.

Gertrude died at home in Ann Arbor. On August 19, 1903, the day she was born, Gertrude's mother was pianist with an ensemble of musicians who had gathered in the parlor in their Chicago, Illinois home. When Gertrude was ready to make her appearance her mother excused herself and went into the bedroom to get on with the backstage activities, while the musicians continued to play. On August 1, 1992, Gertrude's daughter and a neighbor sat beside her, sharing memories from their youth. Some of the stories were funny. While the room was filled with the music of happy laughter, Gertrude made her final bow. 